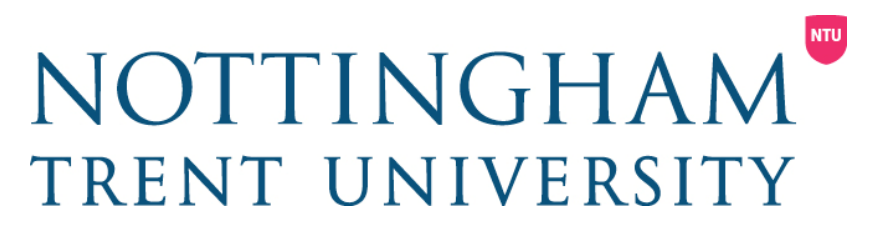

DISCUSSION PAPERS

I $\mathbf{N}$

ECONOMICS

No. 2008/ 12 ISSN 1478-9396

IS REAL GDP PER CAPITA A STATIONARY PROCESS? SMOOTH TRANSITIONS, NONLI NEAR TRENDS AND UNIT ROOT TESTING

J uan Carlos CUESTAS and Dean GARRATT 


\section{DISCUSSI ON PAPERS IN ECONOMICS}

The economic research undertaken at Nottingham Trent University covers various fields of economics. But, a large part of it was grouped into two categories, Applied Economics and Policy and Political Economy.

This paper is part of the new series, Discussion Papers in Economics.

Earlier papers in all series can be found at:

http://www.ntu.ac.uk/research/school_research/nbs/overview/working_papers/index .html

Enquiries concerning this or any of our other Discussion Papers should be addressed to the Editor:

Dr Juan Carlos Cuestas

Division of Economics

Nottingham Trent University

Burton Street

Nottingham, NG1 4BU

UNITED KINGDOM

Email: juan.cuestas@ntu.ac.uk 


\title{
Is real GDP per capita a stationary process? Smooth transitions, nonlinear trends and unit root testing
}

\author{
Juan Carlos Cuestas ${ }^{\dagger}$ \\ Dean Garratt
}

Nottingham Trent University

July 16, 2008

\begin{abstract}
The aim of this paper is to provide additional evidence about the order of integration of constant price GDP per capita in a selection of countries. It does so by taking into account the possibility of non-linear deterministic trends and of asymmetric adjustment towards equilibrium. We find evidence of a global stationary ESTAR process around a nonlinear deterministic trend in almost half of the selected countries. These results show that nonlinearities affect real GDP series. By neglecting them, one can draw misleading conclusions from unit root tests. Specifically, the paper questions the so-called stylised fact of a near unit root which has so influenced macroeconomic thought over the past two decades.
\end{abstract}

J.E.L. Classification : C22; E31; E32.

Key words: Real GDP per capita, unit root tests, persistence, nonlinearities, smooth transitions.

\footnotetext{
${ }^{\dagger}$ Corresponding author: Nottingham Business School, Division of Economics, Nottingham Trent University, Burton Street, NG1 4BU, Nottingham, UK. e-mail: juan.cuestas@ntu.ac.uk. Juan Carlos Cuestas gratefully acknowledges the financial support from the CICYT and FEDER project SEJ2005-01163, the Bancaja project P1.1B2005-03 and the Generalitat Valenciana Complementary Action ACOMP07/102. This author is a member of the INTECO research group. The usual disclaimer applies.
} 


\section{Introduction}

The analysis of the statistical properties of real GDP and real GDP per capita has attracted the attention of a number of authors since Nelson and Plosser's (1982) seminal paper. They argue that the question of whether real GDP is a unit root or a stationary process has both theoretical and policy implications. On the one hand, if real GDP is characterised as a unit root process, shocks affecting the variable have permanent effects. On the other hand, if real GDP is characterised as a stationary process around a deterministic trend there exists a time varying equilibrium real GDP with fluctuations around it depicting the business cycle.

Durlauf (1989) describes the near unit root in measures of aggregate activity, such as constant price per capita GDP, as a 'significant stylised fact'. Its significance has had a major impact on macroeconomic thinking. Nelson and Plosser (1982) argue that the result shows the need for macroeconomists to focus on real shocks which have permanent effects. Specifically, they argue that these shocks are innovations in technology which are frequent and random. The result is that we will observe fluctuations in constant price per capita GDP mapping out the business cycle. Their emphasis was to downplay fluctuations emanating from aggregate demand and to unite the work on short run and long run growth. But, Durlauf (1989) reminds us that the persistence characteristic of GDP need not be associated with one particular school of thought or one model of the economy. For instance, he argues that the persistence can arise out of co-ordination 
failures, such as the stickiness of prices arising from menu costs. Clearly, the 'stylised fact' has affected the development of theory across a diversity of macroeconomic traditions.

Whether or not the GDP series is characterised as having a near unit root is more than a theoretical curiosity. Its importance crucially extends to policy, though exactly how is dependent on the theoretical interpretation given to the result. For example, Li (2000) argues, in the context of China, that the impact on GDP of government policies, such as structural reform, is particularly difficult to predict in the face of other potentially off-setting shocks. Indeed he goes so far as to suggest that it might not be worth pursuing. If, however, GDP is a stationary process around a deterministic trend, Li believes that there is scope for policy-makers to change the long run equilibrium value of the GDP. In contrast, Durlauf (1989) argues that in the presence of persistence stabilisation policy can result in 'very large' social welfare improvements.

The literature on the long run behaviour of real GDP has mainly focussed on testing for unit roots over the series of real GDP, by means of applying traditional (linear) unit root tests, although controlling for structural changes in most cases. Although the literature is very vast, the results are far from conclusive and not wholly supportive of the unit root being a 'stylised fact'. While some authors find that real GDP is a unit root process (Murray and Nelson, 2000; Perron, 1989; and Evans, 1989, among others), others find empirical evidence to reject the null hypothesis of a $\mathrm{I}(1)$ process (Ben-David and Papell, 1995; Vougas, 2007) in US real GDP series. In an empirical study of African 
countries, Chang, Nieh and Wei (2005) apply the Leybourne, Newbold and Vougas (1998) unit root test to detrend the data by means of a logistic function. Their results point to the rejection of the null for some of the countries analysed.

Michael, Nobay and Peel (1997) and Kapetanios, Shin and Snell (2003) (KSS) among others, consider how traditional unit root tests may suffer from a power problem when applied to series characterised by a nonlinear data generating process. Therefore, these tests tend to confuse a unit root process with a globally stationary smooth transition process, i.e. asymmetric speed of mean reversion, for which nonstationarity may characterise one of the regimes. Thus, KSS propose a unit root test based upon the alternative that the series are a globally stationary exponential smooth transition autoregressive (ESTAR) process. Applying this test to the detrending series, by means of a linear trend and a drift, Beechey and Österholm (2008) find evidence of stationarity of the US real GDP per capita.

This paper aims to contribute to the empirical literature on the order of integration of the real GDP per capita in a pool of developed countries, by applying the KSS test to the detrended and demeaned data, following the Beechey and Österholm (2008) approach. While our initial results point to the non-rejection of the unit root hypothesis for all of the countries, it is well known within the literature of unit root testing that misspecification of the deterministic components can affect the power of the tests (Perron and Phillips, 1987; West, 1988; and Bierens, 1997, among others). This is related to need to take into account 
structural breaks in unit root testing (Perron, 1989, 1990) and a broken time trend is a particular case of a nonlinear time trend. In order to take into account the possibility of nonlinear trends, as well as asymmetric adjustment in mean reversion, we also apply the KSS test for the demeaned and detrended data. In doing this, the nonlinear trend is approximated by a cubic function so as to take into account the descriptive features of the data.

\section{Econometric methodology and results}

In this section we apply several linear and nonlinear unit root techniques in order to test for the order of integration of the real GDP per capita in a panel of developed countries. The data cover annual real GDP per capita from 1870 until 2003, obtained from Professor Angus Maddison's webpage ${ }^{1}$.

As a preliminary analysis, we apply the linear unit root tests developed by $\mathrm{Ng}$ and Perron (2001). These authors propose some modifications of existing unit root tests, in order to improve their power and size: $M Z_{\alpha}$ and $M Z_{t}$ that are the modified versions of the Phillips (1987) and Phillips and Perron (1988) $Z_{\alpha}$ and $Z_{t}$ tests; the $M S B$ that is related to the Bhargava (1986) $R_{1}$ test; and, finally, the $M P_{T}$ test that is a modified version of the Elliot, Rothenberg and Stock (1996) Point Optimal Test. The results of applying these tests are reported in Table 1. The proper lag length has been selected

\footnotetext{
${ }^{1}$ http://www.ggdc.net/maddison.
} 
by the Akaike Information Criterion, from a maximum of 4 lags. We find, even after including a deterministic trend and intercept in the auxiliary regressions, that it is not possible to reject the null hypothesis of a unit root.

As mentioned before, linear unit root tests can suffer from power problems in the presence of nonlinearities in the data. Therefore, their results may be biased towards the non-rejection of the null hypothesis. Thus, KSS propose a unit root test based on the following modified Augmented Dickey Fuller (ADF) regression,

$$
\Delta y_{t}=\alpha y_{t-1}+\gamma y_{t-1}\left(1-\exp \left\{-\theta y_{t-1}^{2}\right\}\right)+\epsilon_{t}
$$

in order to test for unit roots. Note that this regression implies that the autoregressive parameter changes smoothly depending on the values of the variable $y_{t}$. Since KSS impose $\alpha=0$, the variable is assumed to be a unit root in the central regime. In order to test the null hypothesis of a unit root, $H_{0}: \theta=0$, against the alternative of a globally ESTAR process, $H_{1}: \theta>0$, Kapetanios et al. (2003) propose the following Taylor approximation of model (2.1), given that the coefficient $\gamma$ cannot be identified under $H_{0}$,

$$
\Delta y_{t}=\delta y_{t-1}^{3}+\text { error }
$$

It is now possible to apply a $t$-statistic to test whether $y_{t}$ is a $\mathrm{I}(1)$ process, $H_{0}: \delta=0$, or is a $\mathrm{I}(0)$ process, $H_{1}: \delta<0$. Of course, equation (2.2) may also incorporate lags to control for autocorrelation in the residuals. 
In Table 2 we report the results of the KSS test ${ }^{2}$. Although KSS report the critical values for various sample sizes, in the present paper we obtain the critical values for the exact sample size used by Monte Carlo simulations based on 50,000 replications. The second column contains the results for the unit root analysis of the demeaned and linearly detrended data, i.e. $y_{t}=y_{t}^{R}-\hat{\alpha}-\hat{\beta} t$, where $y_{t}^{R}$ is the raw data. These results still point to the non-rejection of the null hypothesis. Nevertheless, as aforementioned, incorrectly specifying the deterministic components may produce misleading results in favour of the null. In figure 1 we plot the series of real GDP per capita for some of the countries $^{3}$. The long run path of this variable appears to follow a nonlinear trend, where a cubic function seems to be appropriate as a proxy of the deterministic trend. Therefore, we have also applied the KSS test to the detrended data, following the specification $y_{t}=y_{t}^{R}-\hat{\alpha}-\hat{\beta} t-\hat{\delta} t^{2}-\hat{\gamma} t^{3}$. The results are reported in the last column, table 2, which point to the rejection of the null hypothesis of unit root against the alternative of globally stationary ESTAR process around a (cubic) nonlinear deterministic trend in 9 of the 19 countries.

\footnotetext{
${ }^{2} \mathrm{As}$ in the case of the $\mathrm{Ng}$ and Perron (2001) results, the lag length has been chosen by the Akaike Information Criterion, from a maximum of 4 lags.

${ }^{3}$ Similar paths are followed by the rest of the countries that for space matters have been omitted. However, they are available upon request to the corresponding author.
} 


\section{Conclusions}

This paper aims to contribute to the literature on the order of integration of the real GDP per capita. To do so we have applied a group of unit root tests, taking into account the possibility of asymmetric adjustment and nonlinear trends. The results show that once these two sources of nonlinearities have been controlled for the real GDP per capita series in some of the selected countries is a stationary process. This finding is highly significant for macroeconomists. It refutes, for some countries at least, the so-called stylised fact that measures of aggregate activity, like GDP per capita, have a near unit root. Hence, it fuels the debate over the persistence of shocks to GDP series. Our results show that we can indeed portray GDP as mean-reverting around a deterministic trend. Nonetheless, there remains much to be done to deepen our understanding of both the properties and determination of the deterministic trend. Indeed our findings raise intriguing questions about possible differences across countries in the persistence of GDP shocks.

\section{References}

Beechy, M. and P. Österholm (2008): "Revisiting the uncertain unit root in GDP and CPI: testing for non-linear trend reversion", Economics Letters, forthcoming.

Ben-David, D. and D. H. Papell (1995): "The great wars, the great crash, and the steady 
state growth: some new evidence about an old stylized fact", Journal of Monetary Economics, vol. 36, pp. 453-475.

Bhargava, A. (1986): "On the theory of testing for unit roots in observed time series", Review of Economics Studies, vol. 53, pp. 369-384.

Bierens, H. J. (1997): "Testing the unit root with drift hypothesis against nonlinear trend stationarity, with an application to the U.S. price level and interest rate", Journal of Econometrics, vol. 81, pp. 29-64.

Chang, T., C.-C. Nieh and C.-C. Wei (2005): "Is per capita real GDP stationary? evidence from selected African countries based on more powerful nonlinear (logistic) unit root tests", Economics Bulletin, vol. 3, pp. 1-9.

Durlauf, S. N. (1989): "Output persistence, economic structure, and the choice of stabilization policy", Brookings Papers of Economic Activity, vol. 2, pp. 69-136.

Elliot, G., T. J. Rothenberg and J. H. Stock (1996): "Efficient tests for an autoregressive unit root", Econometrica, vol. 64, pp. 813-836.

Evans, G. W. (1989): "Output and employment dynamics in the united states", Journal of Applied Econometrics, vol. 4, pp. 213-237.

Kapetanios, G., Y. Shin and A. Snell (2003): "Testing for a unit root in the nonlinear STAR framework", Journal of Econometrics, vol. 112, pp. 359-379. 
Leybourne, S. J., T. C. Mills and P. Newbold (1998): "Spurious rejections by DickeyFuller tests in the presence of a break under the null", Journal of Econometrics, vol. 87, no. 1, pp. 191-203.

Li, X.-M. (2000): "The great leap forward, economic reforms, and the unit root hypothesis: testing for breaking trend functions in China's GDP data", Journal of Comparative Economics, vol. 28, pp. 814-827.

Michael, P., A. Nobay and D. Peel (1997): "Transaction costs and nonlinear adjustment in real exchange rates: An empirical investigation", Journal of Political Economy, vol. 105, pp. $862-879$.

Murray, C. J. and C. R. Nelson (2000): "The uncertain trend in U. S. GDP", Journal of Monetary Economics, vol. 46, pp. 79-95.

Nelson, C. R. and C. I. Plosser (1982): "Trends and random walks in macroeconomic time series", Journal of Monetary Economics, vol. 10, pp. 139-162.

Ng, S. and P. Perron (2001): "Lag selection and the construction of unit root tests with good size and power", Econometrica, vol. 69, pp. 1519-1554.

Perron, P. (1989): "The Great Crash, the Oil Price Shock and the unit root hypothesis", Econometrica, vol. 57, pp. 1361-1401.

Perron, P. (1990): "Testing for a unit root in a time series with a changing mean", Journal of Business and Economic Statistics, vol. 8, pp. 153-162. 
Perron, P. and P. C. B. Phillips (1987): "Does GNP have a unit root? A reevaluation", Economics Letters, vol. 23, pp. 139-145.

Phillips, P. C. B. (1987): "Time series regression with a unit root", Econometrica, vol. 55, pp. 311-340.

Phillips, P. C. B. and P. Perron (1988): "Testing for a unit root in time series regression", Biometrica, vol. 75, pp. 335-346.

Vougas, D. V. (2007): "Is the trend in post-WW II US real gdp uncertain or non-linear?", Economics Letters, vol. 94, pp. 348-355.

West, K. D. (1988): "Asymptotic normality when regressors have a unit root", Econometrica, vol. 56, pp. 1397-1418. 
Figure 1: Real GDP per capita and nonlinear trends

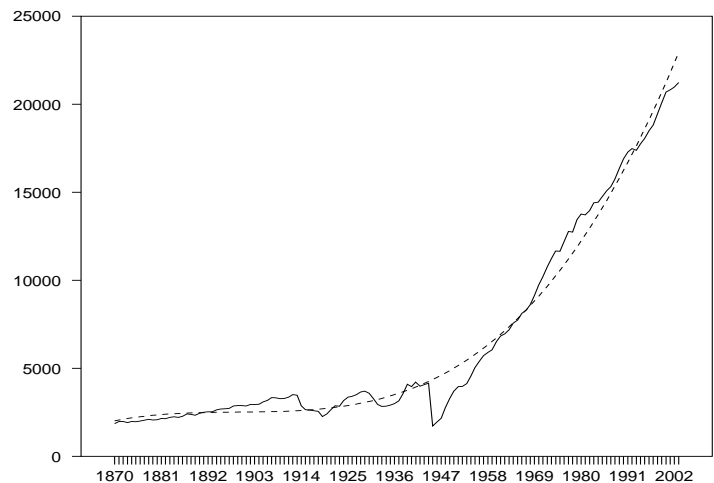

(a) Australia

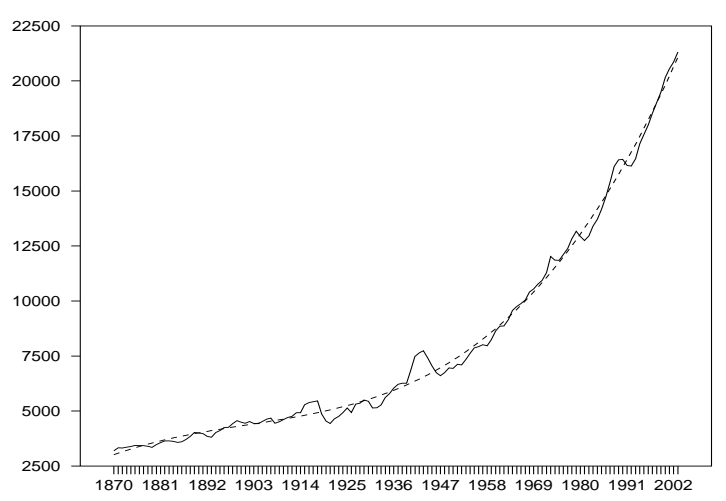

(c) United Kingdom

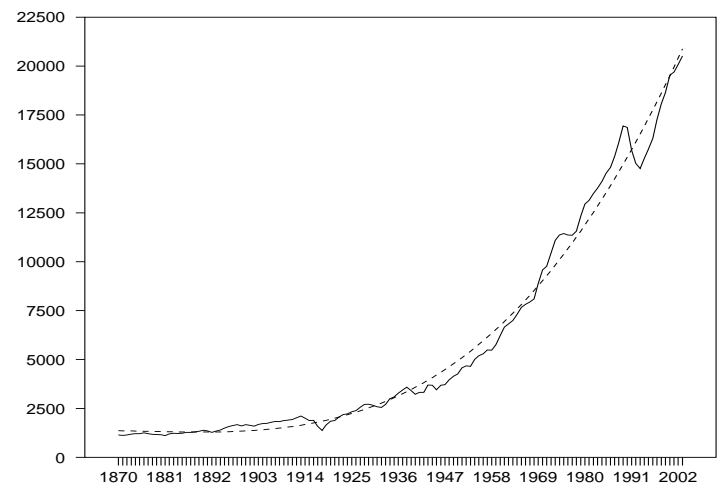

(b) Finland

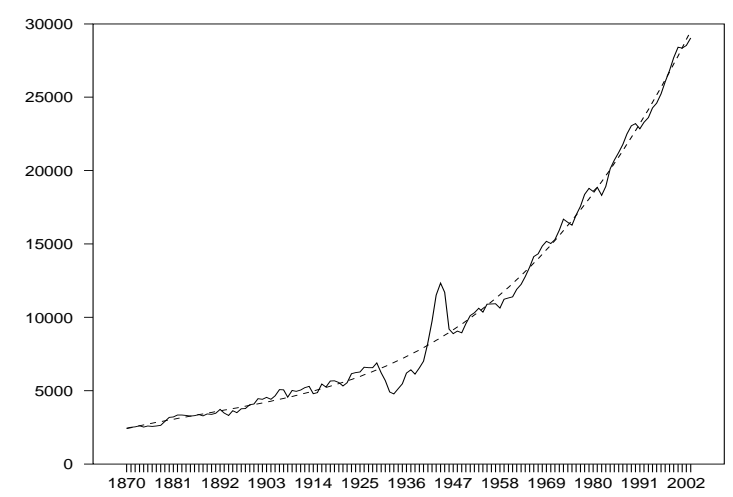

(d) United States 
Table 1: Ng and Perron (2001) unit root tests results

\begin{tabular}{lcccc}
\hline Country & $M Z_{\alpha}$ & $M Z_{t}$ & $M S B$ & $M P_{T}$ \\
\hline Australia & 0.39665 & 0.17511 & 0.44147 & 52.1362 \\
Austria & -0.41135 & -0.19426 & 0.47225 & 52.3966 \\
Belgium & -1.78104 & -0.65471 & 0.36760 & 32.0920 \\
Canada & -0.57350 & -0.25263 & 0.44051 & 46.5535 \\
Denmark & -0.26768 & -0.13231 & 0.49427 & 57.0345 \\
Finland & 0.26163 & 0.13354 & 0.51042 & 63.8351 \\
France & -1.27426 & -0.53192 & 0.41743 & 39.7574 \\
Germany & -1.66170 & -0.69288 & 0.41697 & 37.7623 \\
Italy & 0.18739 & 0.11790 & 0.62920 & 88.6784 \\
Japan & -2.27265 & -0.85440 & 0.37595 & 30.9051 \\
Netherlands & -0.30985 & -0.15416 & 0.49752 & 57.2960 \\
New Zealand & -1.20392 & -0.47044 & 0.39075 & 36.9282 \\
Norway & -2.61080 & -0.82630 & 0.31649 & 25.1201 \\
Portugal & 0.22092 & 0.11727 & 0.53084 & 67.5398 \\
Spain & -1.50929 & -0.50652 & 0.33560 & 30.0255 \\
Sweden & -0.55393 & -0.25503 & 0.46040 & 49.6433 \\
Switzerland & -1.59257 & -0.78657 & 0.49390 & 47.6669 \\
United Kingdom & 0.33548 & 0.14351 & 0.42779 & 49.5120 \\
United States & -1.62077 & -0.58288 & 0.35963 & 31.9296 \\
\hline \hline
\end{tabular}

Note: The order of lag to compute the test has been chosen using the modified AIC (MAIC) suggested by Ng and Perron (2001). Rejection of the null hypothesis at the $10 \%$ significance level is given by * The critical values for the above tests have been taken from Ng and Perron (2001):

\begin{tabular}{ccccc}
\multicolumn{4}{c}{ Model with constant and linear trend } \\
\hline \hline & $M Z_{\alpha}$ & $M Z_{t}$ & $M S B$ & $M P_{T}$ \\
\hline $1 \%$ & -23.80 & -3.42 & 0.14 & 4.03 \\
$5 \%$ & -17.30 & -2.91 & 0.16 & 5.48 \\
$10 \%$ & -14.20 & -2.62 & 0.18 & 6.67 \\
\hline
\end{tabular}


Table 2: KSS nonlinear unit root test results

\begin{tabular}{lcc}
\hline \hline Country & KSS(t) & KSS(t $\left.\mathbf{t}^{3}\right)$ \\
\hline Australia & 1.97196 & $-4.60951^{* * *}$ \\
Austria & -1.44213 & -2.73429 \\
Belgium & -0.15549 & -2.43742 \\
Canada & -0.93022 & -3.30643 \\
Denmark & -1.14022 & -2.98435 \\
Finland & -0.33715 & $-5.75477^{* * *}$ \\
France & -2.04724 & -3.54531 \\
Germany & -2.82152 & -3.28761 \\
Italy & -0.96981 & -3.12118 \\
Japan & -1.72213 & -1.44496 \\
Netherlands & -2.34353 & $-5.17520^{* * *}$ \\
New Zealand & -0.91824 & -2.75196 \\
Norway & 0.01040 & $-5.83889^{* * *}$ \\
Portugal & -0.64843 & $-4.88731^{* * *}$ \\
Spain & 1.11371 & -2.30296 \\
Sweden & -0.58825 & $-4.12540^{* *}$ \\
Switzerland & -2.74087 & $-3.80560^{*}$ \\
United Kingdom & 1.26174 & $-3.86867^{*}$ \\
United States & -0.25982 & $-4.71937^{* * *}$ \\
\hline \hline
\end{tabular}

Note: The test has been computed including a constant and a linear time trend as deterministic component. The order of lag for the auxiliary regression has been selected by the AIC. Critical values at the $10 \%, 5 \%$ and $1 \%$ for the $\operatorname{KSS}(\mathrm{t})$ test are $-3.103877,-3.388891$ and -3.942044 , whereas for the $\operatorname{KSS}\left(\mathrm{t}^{3}\right)$ test are $-3.729372,-4.028135$ and -4.608279 , respectively and have been computed by Monte Carlo simulation with 50,000 replications. Rejection of the null hypothesis at the $10 \%, 5 \%$ and $1 \%$ significance level are given by the symbols ${ }^{*},{ }^{* *}$ and ${ }^{* * *}$, respectively. 


\section{DISCUSSION PAPERS I N ECONOMI CS}

2008/11 Antonio Rodriguez Andres and Carlyn Ramlogan-Dobson, Corruption, privatisation and the distribution of income in Latin America

2008/10 Stephen Dobson and Carlyn Ramlogan, Is there an openness Kuznets curve? Evidence from Latin America

2008/9 Stephen Dobson, John Goddard and Frank Stähler, Effort levels in contests: an empirical application of the Tullock model

2008/8 Juan Carlos Cuestas and Estefania Mourelle, Nonlinearities in real exchange rate determination: Do African exchange rates follow a random walk?

2008/7 Stephen Dobson and J ohn Goddard, Strategic behaviour and risk taking in football

2008/6 J oao Ricardo Faria, Juan Carlos Cuestas and Estefania Mourelle, Entrepreneurship and unemployment: A nonlinear bidirectional causality?

2008/5 Dan Wheatley, Irene Hardill and Bruce Philp, "Managing" reductions in working hours: A study of work-time and leisure preferences in the UK industry

2008/4 Adrian Kay and Robert Ackrill, Institutional change in the international governance of agriculture: a revised account

2008/3 Juan Carlos Cuestas and Paulo José Regis, Testing for PPP in Australia: Evidence from unit root test against nonlinear trend stationarity alternatives

2008/2 João Ricardo Faria, Juan Carlos Cuestas and Luis Gil-Alana, Unemployment and entrepreneurship: A Cyclical Relation

2008/1 Zhongmin Wu, Mark Baimbridge and Yu Zhu, Multiple Job Holding in the United Kingdom: Evidence from the British Household Panel Survey

\section{SCUSSI ON PAPERS I N POLITI CAL ECONOMY}

2006/3 I oana Negru, On Homogeneity and Pluralism within Economics Schools of Thought

2006/2 David Harvie and Bruce Philp, Learning and Assessment in a Reading Group Format or Reading Capital... For Marks

2006/1 David Harvie, Bruce Philp and Gary Slater, Regional Well-Being and 'Social Productivity' in Great Britain'

2004/2 Massimo De Angelis and David Harvie, Globalisation? No Question: Foreign Direct Investment and Labour Commanded

2004/1 David Harvie, Value-Production and Struggle in the Classroom, or, Educators Within, Against and Beyond Capital

\section{DISCUSSION PAPERS IN APPLIED ECONOMI CS AND POLICY}

2007/2 Juan Carlos Cuestas, Purchasing Power Parity in Central and Eastern European Countries: An Analysis of Unit Roots and Non-linearities

2007/1 Juan Carlos Cuestas and Javier Ordóñez, Testing for Price Convergence among Mercosur Countries

2006/2 Rahmi Cetin and Robert Ackrill, Foreign Investment and the Export of Foreign and Local Firms: An Analysis of Turkish Manufacturing

2006/1 Robert Ackrill and Adrian Kay, The EU Financial Perspective 2007-2013 and the Forces that Shaped the Final Agreement

2004/5 Michael A. Smith, David Paton and Leighton Vaughan-Williams, Costs, Biases and Betting markets: New evidence 
2004/4 Chris Forde and Gary Slater, Agency Working in Britain: Character, Consequences and Regulation

2004/3 Barry Harrison and David Paton, Do 'Fat Tails' Matter in GARCH Estimation? Stock market efficiency in Romania and the Czech Republic

2004/2 Dean Garratt and Rebecca Taylor, Issue-based Teaching in Economics

2004/1 Michael McCann, Motives for Acquisitions in the UK

2003/6 Chris Forde and Gary Slater, The Nature and Experience of Agency Working in Britain

2003/5 Eugen Mihaita, Generating Hypothetical Rates of Return for the Romanian Fully Funded Pension Funds

2003/4 Eugen Mihaita, The Romanian Pension Reform

2003/3 Joshy Easaw and Dean Garratt, Impact of the UK General Election on Total Government Expenditure Cycles: Theory and Evidence

2003/2 Dean Garratt, Rates of Return to Owner-Occupation in the UK Housing Market

2003/1 Barry Harrison and David Paton, The Evolution of Stock Market Efficiency in a Transition Economy: Evidence from Romania 